\title{
Determinants of Economic Growth in V4 Countries and Romania
}

\author{
- Simionescu Mihaela, Lazányi Kornélia, Sopková Gabriela, Dobes Kamil, \\ Balcerzak Adam P.
}

\begin{abstract}
The middle and long-term slowdown in growth dynamics could bring serious social and political problems for V4 countries (Czech Republic, Slovak Republic, Hungary, Poland) and Romania. It would threaten reaching benefits from potential of convergence process with the developed countries of the European Union. As a result, the V4 economies and Romania should find solutions to achieving a sustainable growth that is associated with an improvement of their international competitiveness. This paper provides an empirical analysis of factors that might determine a stable economic growth in the five mentioned countries. The empirical analysis conducted for the period of 2003-2016 employed Bayesian generalized ridge regression. The main results indicated that the FDI promoted economic growth in all countries, except the Slovak Republic. Only in the Czech Republic, the expenditure on education generated economic growth, while the expenditure on R\&D had positive effects in Romania, Hungary and the Czech Republic.
\end{abstract}

Keywords: economic growth, V4 countries, FDI, buman capital, R\&D, investments in education JEL Classification: C 51, C 53, O 47

\section{INTRODUCTION}

The growth rate of the gross domestic product is the main indicator used in evaluating performance of every economy. The international context marked by the recent global economic crisis brought a decrease in economic performance in all member states of the EU. In case of the new EU countries, this phenomenon can threaten a quick improvement in welfare of their societies, which can be obtained under condition of utilising the benefits of convergence process supported by effective middle and long-term development policy. In this context, the main objective of this paper is to provide an analysis of determinants of economic growth in the V4 countries (Czech Republic, Slovak Republic, Hungary, Poland) and Romania.

The research was conducted for the years of 2003-2016. Considering the small set of data, a Bayesian approach was implemented by estimations of Bayesian generalized ridge regression.

In the research, we chose V4 countries and Romania, as the two spatial entities are new EU member states, but they are quite different in terms of the stage of economic development. The Visegrad countries are the most industrialized economies among new EU members. The Group is characterized by a relatively high income and high Human Development Index. If these states are considered as single economy, it represents the fifth economic power in Europe. According to the data for 2015 available, the Czech Republic is the most developed country with the GDP per capita in PPP of 32,622 USD, being followed by the Slovak Republic, Poland and Hungary (with the value of USD 26,941 per capita). On the other hand, Romania is placed among the less 
developed states after the EU enlargement in 2007. The country is considered to be an uppermiddle income economy. In 2015, the GDP per capita in PPP in Romania was only 20,787 USD. However, Romania proved to have one of the most rapidly growing economy in the EU. In 2007, the GDP per capita in PPS was at $41 \%$ of the EU average value and it increased up to $57 \%$ of the average in 2015. This can be a confirmation of relatively quick convergence of this economy with the EU countries. As a result, from the comparative point of view and taking into account the importance of building conditions for sustainable economy in the whole Europe, the research on the V4 countries and Romania with their macroeconomic and structural differences can provide important policy guidelines.

In the next section, some key points related to determinants of economic growth in the V4 countries and Romania are discussed. The second section provides a brief description of the methodological background for an empirical research. Then, the empirical analysis of determinants of economic growth in the V4 states and Romania is provided. The article ends with conclusions and suggestions for future research.

\section{LITERATURE REVIEW}

The economy's competitiveness is commonly associated with the economic performance measured by economic growth. The main policy objective of a country is to stimulate output as a necessary base for economic and social development. As Vojtovic (2013) pointed out, the determinants of economic growth might change in space and time. Depending on the methodological, theoretical approach (exogenous or endogenous growth theory) or time span analysis (short, middle or long-term perspective), the set of specific factors (variables) related to economic growth that are often taken into consideration is relatively broad (Barro, 1991; Sala-I-Martin, 1997). Among the factors that are commonly included in the growth regression equations, one can usually find such basic economic indicators as employment, inflation, current account balance, government debt, export and imports, FDI, capital formation, etc., but also other variables related to the quality and quantity of labour resources in a country, natural resources, technological development or social and political factors.

However, recent economic literature identified two key structural determinants of economic growth: the globalization of world economy with the associated liberalization of world trade and the fast development of information and communication technologies (KondratiukNierodzińska, 2016; Balcerzak \& Pietrzak, 2016; Mahdi Ghodsi \& Michalek, 2016; StefaniakKopoboru \& Kuczewska, 2016). These two determinants are also key points for understanding the type and sources of competitiveness (Ivanova et al, 2015).

The relationship between globalisation and human development in post-transition countries in the years 1971-2010 was investigated by Cieślik (2014), who applied a pannel data modelling. He confirmed that there exists a positive and statistically significant relationship between globalization and human development in case of the unconditional regressions. Additonally, the obtained relationship was also positive and significant once the process of European and regional integration was controlled for. On the other hand, after taking into account differences in the level of economic development, the globalization variable lost its statistical significance. 
Capello and Perucca (2015) proved that globalization had a positive effect on the EU integration and promoted the economic performance of CEE countries, including Romania and the V4 countries. Many factors concerning dimensions of globalisation were considered by Gurgul and Lach (2014) for the V4 countries, Romania and other CEE states in the years 1990-2009. The information flow, economic globalization (development of international trade, an increase in FDI, a decrease in import barriers and development of tax policy) and social globalization (internet, television and newspapers) had a strong impact on economic growth in the countries mentioned.

In the context of economic globalization, FDI is often considered key determinant of economic growth. The V4 states attracted a significant amount of FDI before the crisis due to favourable economic environment for investors and an openness to international capital mobility. Besides, the promotion of economic growth, FDI tends to contribute to the new jobs creation, increase in the labour productivity, a more efficient allocation of resources, a better competitiveness of the economy and less regional disparities (Moura and Forte, 2010).

However, according to Simionescu (2016), FDI did not generate economic growth in Romania after the crisis, but a higher economic growth attracted more foreign investors. There are also the studies showing that in the V4 countries, FDI did not have the expected positive effects on the unemployment (Iwasaki and Tokunaga, 2013) or the positive influence was only short-term (Balcerzak \& Żurek, 2011).

In the empirical literature devoted to determinants of growth in Central European economies, a lot of attention is accorded to the role of European integration and the EU enlargements. The studies usually confirm that in the case of theV4 countries in the period before the recent economic crisis, a relatively quick and to some extant sustainable growth was supported by the utilisation of the EU funds and achievement of convergence criteria (Nežinský and Fifeková, 2014; Sass and Fifekova, 2011). Ivanova et al. (2014) showed that a long-run economic growth was registered in the V4 states in 1995-2013 mainly because of the fast rhythm of growth after the EU accession. The real GDP rate was 1.7 percentage points greater than the value in the EU-15 countries in the period described. The authors consider that the main cause of this fast economic growth was the technological catch-up with the most developed economies of the EU.

In the context of technological potential and potential competitive advantages of the region a quality of human capital, sometimes reflected by education, has been the subject of many studies that analysed determinants of economic growth in the CEE countries, Romania and V4 countries being included in this group of states. According to Supińska (2013), who used a spatial approach to detect the output determinants, human capital and the changes in this indicator promoted economic growth in the regions of 10 CEE states in 1990-2008. Balcerzak and Pietrzak applied the Cobb-Douglas production function approach in estimating changes in the total factor productivity (TFP) in the new EU members in the years 2000-2010 and then proposed its endogenisation with application of dynamic panel modelling. As a result, they were able to confirm a significant influence of the quality of human capital on the level of TFP in the new EU member states. Moreover, Cuaresma et al. (2014) showed that the regions around the capitals of the new members of the EU grew rapidly because of more educated labour resources in 1995-2005. 
In the context of competitive potential in the reality of knowledge based economy, the role of research and development investments (R\&D) is also often taken into consideration (Bilas et al., 2016). In spite of the fact that the R\&D expenditure is commonly treated as the most important investment in building knowledge based economy - the need for increasing the scale of investments in this field in all European countries up to 3\% of GDP was the most recognised agenda of Lisbon Strategy and is also included in Europe 2020 strategy - the empirical research shows that that the influence of $R \& D$ on the growth process is very complex. As a result, an effective utilisation of R\&D expenditure depends on many institutional and even to some extent social factors. Therefore, the positive influence of R\&D on growth is not automatic (Piech, 2007; Witkowski, 2007; Balcerzak and Pietrzak, 2015).

Social factors are considered important determinants of economic growth by Harrison and Huntington (2000) who put into relationship the people behaviour with aspects related to output growth: investment, consumption, savings and expectations related to economic issues. The relationship between economic growth and social determinants in Romania and other EU states was studied by Popa (2012), who identified factors that are positively correlated to output growth (life expectancy, years of schooling) and factors that are negatively correlated with economic growth (unemployment rate, poverty risk).

In recent years, in the context of institutional and social determinants of growth factors much harder to capture, embedded in the values and attitudes of the people are also taken into consideration. For example, factors such as trust and social support, which are often considered to be components of social capital, are also included in the growth regression equations. On the basis of the World Values Survey, Zak and Knack (2001) pointed out that trust is positively associated with important economic factors, such as growth of per capita income and GDP along with other standard determinants of economic performance. For example, $7 \%$ growth in interpersonal trust was measured to rise investments as a share of GDP by $1 \%$. The importance of such components of social or cooperation capital like trust, helpfulness and fairness was also confirmed econometrically by Ambroziak et al. (2016) with application of a model based on a modified and augmented Cobb-Douglas function. The authors conducted research for the years of 2006-2012 with application of a sample of 22 European countries (in the sample Hungary, Poland and Slovakia were included). The research confirmed that $1 / 6$ of the economic growth measured by the GDP growth rate can be attributed to the effects of an increase in cooperation capital. The findings have also been supported by the research of the National Bureau of Economic Research (Hamilton et al., 2016) stating that the value of trust as an asset is comparable to the value of produced capital per person in such a clear cut manner that from a policy perspective the increase in the social capital and trust should be one of the most targeted territories of investment.

In the context of intangible output determinants, political factors are also analysed as the ones that can have impact on economic growth. A study made for the CEE countries by Radu (2015) showed that the economic growth was influenced in 1990-2010 by political certainty and stability and by political freedom.

The natural resources utilisation tends to have a considerable impact on the economy evolution. The impact of energy consumption on economic growth was studied in the late seventies by Kraft and Kraft (1978), but there is also a lot of recent papers that reconsider the relationship be- 
tween energy consumption and economic growth in various countries. For the V4 states, Kasperowicz and Śtreimikienè (2016) showed that the energy consumption was positively correlated with economic growth, being a cause of output increase in the period of 1995-2012. The intensity of this relationship for V4 countries was higher than in old 14 EU countries in the same period.

In the case of empirical research that takes into considered a wide set of factors mentioned above, one can point to Próchniak (2011), who concentrated on 10 countries from Central and Eastern Europe (the V4 countries, Romania, Slovenia, Bulgaria, Estonia, Latvia, Lithuania) in the years 1993-2009. He identified a following set of determinants of economic growth in the region: investment (FDI was included here), work force level of education, good fiscal stance, development of the financial sector, low inflation, low interest rate, high private sector share in output, structure of the population, fast development of information technology and communications, good institutional environment (a significant progress in structural reforms and market, economic freedom).

\section{METHODOLOGY}

The basic regression models might provide misleading results when empirical data are used. The issue is met when the method assumptions are violated. In this context, the regression model should reflect all possible patterns in the data. This limit is eliminated by the Bayesian nonparametric approach that proposes flexible models as an infinite mixture of regression models based on minimum assumptions on data.

The ridge regression linear model brings estimates via shrinkage by improving the prediction error and the mean squared error.

For a certain data series, $D_{n}=(X, y)$ with $X=\left(x_{i p}\right)_{n \times p}$ and $y=\left(y_{1}, \ldots, y_{n}\right)^{T}$ and a conjugate normalinverse gamma prior density to $\left(\beta, \sigma^{2}\right)$.

$f\left(y \mid X, \beta, \sigma^{2}\right)=n_{n}\left(y \mid X \beta, \sigma^{2} I_{n}\right)=\prod^{n}{ }_{i=1} n\left(y \mid x_{i}^{T} \beta, \sigma^{2}\right)$

$\pi\left(\beta, \sigma^{2}\right)=n_{p}\left(\beta \mid m, \sigma^{2} V\right) i g\left(\sigma^{2} \mid a, b\right)=n i g\left(\beta, \sigma^{2} \mid m, V, a, b\right)$

$n_{n}(. \mid \mu, \Sigma)$ - probability density function (pdf) of the $\mathrm{n}$-variate normal distribution

$n\left(\cdot \mid \mu, \sigma^{2}\right)$ - probability density function (pdf) of the uni-variate normal distribution

$i g(\cdot \mid a, b)$ - probability density function (pdf) of the inverse gamma distribution (a is the shape and $\mathrm{b}$ represents the rate, $1 / \mathrm{b}$ is the scale)

$n i g\left(\beta, \sigma^{2} \mid m, V, a, b\right)$ - probability density function (pdf) of the NIG distribution (product of $2 \mathrm{pdf}$ functions corresponding to the inverse-gamma and multivariate normal, as in Lindley and Smith, 1972)

If joint prior distribution of $\left(\beta, \sigma^{2}\right)$ follows a NIG distribution, in the marginal approach, $\beta$ follows a Student prior distribution of mean $\mathrm{m}$ and covariance matrix $V 1(\beta)=b /(a-1) V$ and $2 \mathrm{a}$ degrees of freedom. $\sigma^{2}$ follows an inverse-gamma prior distribution of mean $b /(a-1)$ and variance $b^{2} /\left((a-1)^{2}(a-2)\right)$. 
According to Karabatsos (2014), the ridge regression model (RR model) is a Bayesian linear regression model of normal prior distribution $n_{p}\left(\beta \mid 0, \sigma^{2} \lambda-1 I_{p}\right)$ for $\beta$, conditionally on $\sigma^{2}$. If $\left(\beta, \sigma^{2}\right)$ follows a prior normal inverse-gamma distribution $\operatorname{nig}\left(\beta, \sigma^{2} \mid 0, \lambda^{-1} \mathrm{I}_{\mathrm{p}}, \mathrm{a}, \mathrm{b}\right)$, then the inferential procedures for Bayesian normal linear regression model are used for a ridge regression.

The singular value decomposition (svd) for design matrix $X$ is $X=U D W^{T}$. Here, $U$ and $W$ are orthogonal matrices of $\mathrm{n} \times q$, respectively $p \times q$, where $q=\min (n, p)$ and $Z=U D=X W$.

$D=\operatorname{diag}(d 1, \ldots, d q)$ is a diagonal matrix of singular values $\mathrm{d}_{1}>\mathrm{d}_{2}>\cdots>\mathrm{d}_{\mathrm{q}}>0$

$\left(d_{1}{ }^{2}, \ldots, d_{q}^{2}\right)$ gives at most the first q eigenvalues (q different from $\left.0, \mathrm{q} \leq \mathrm{p}\right)\left(d_{1}{ }^{2}, \ldots, d_{q}{ }^{2}\right)^{T}$ of $X^{T} X$ and gives the diagonal values of $Z^{T} Z$.

The $q$ principal components of $X$ are included in the columns of $X W$. The column-wise sum of squares over the rows represents the eigenvalues $\left(d_{1}^{2}, \ldots, d_{q}^{2}\right)$.

For the orthogonalized data $(Z, y)$, the multivariate normal likelihood density for canonical normal linear model is represented by:

$n_{n}\left(y \mid X W \alpha=Z \alpha=X \beta, \sigma^{2} I_{n}\right)$

The OLS estimate for the coefficients of canonical regression is:

$\hat{\alpha}=\operatorname{diag}\left(d_{1}^{2}, \ldots, d_{q}^{2}\right)^{-1} Z^{T} y$

The OLS estimate for the slope is:

$\hat{\beta}=W \hat{\alpha}$

The conditional prior distribution for $\beta=W \alpha$, when $\sigma^{2}$ is known, follows a multivariate normal pdf that is the prior distribution (pdf) for generalized ridge regression:

$\pi\left(\beta \sigma^{2}\right)=\mathrm{n}\left(\beta \mid 0, \sigma^{2} \mathrm{WV}_{\lambda}{ }^{(\alpha)} \mathrm{W}^{\mathrm{T}}\right)$

A special case of generalized ridge regression is represented by the ordinary ridge regression (RR). It is based on the assumption that $\lambda=\lambda_{1}=\lambda_{2}=\cdots=\lambda_{q}$. In this specific situation, we have:

$\pi\left(\beta \sigma^{2}\right)=\mathrm{n}\left(\beta \mid 0, \sigma^{2} \lambda^{-1} \mathrm{I}_{\mathrm{p}}\right)$

$\pi\left(\alpha \mid \sigma^{2}\right)=\mathrm{n}\left(\alpha \mid 0, \sigma^{2} \lambda^{-1} \mathrm{I}_{\mathrm{p}}\right)$

The ridge regression permits a rapid OLS estimation of the parameters, even if the number of covariates $(p)$ is high and the number of covariates is greater than the number of observations. This approach employing a large number of parameters is specific to Bayesian nonparametric models. This specification with many parameters is made for robust and flexible statistical inference.

For a flexible linear model where $\mathrm{p}$ increases with $\mathrm{n}$, the mean function is represented as:

$E(Y \mid x)=X^{T} \beta=\sum_{k=1}^{L} \beta_{k} x_{k}+\sum_{i=1}^{n} \beta_{i} B_{i}(x)$

$B_{i}(x)$ - multivariate spline

$\sum_{i=1}^{n} \beta_{i} B_{i}(x)$ represents a linear combination of basis functions that includes the departures of linearity of the regression function 
In our empirical application, we have to determine the best predictors for economic growth. We provide estimations of marginal posterior estimates and the posterior probability that the standardized coefficient is within 1 standard deviation of 0 (PP1SD). If the value of PP1SD is lower than 0.5 , then an explanatory variable is selected as a significant predictor in the ridge regression.

\section{DATA AND DISCUSSION OF RESULTS}

The following variables were considered in current empirical analysis: real GDP growth (as \%), inflation rate $(\%)$ based on a harmonized price index, employment rate (as percentage of total population of ages between 15 and 64), FDI inflows as \% of GDP, work force with secondary and tertiary education (percentage of total labour force), government expenditure on education as percentage of GDP, expenditure on research and development (percentage of GDP). Only for the real GDP rate, inflation and employment rate, the data were provided by Eurostat. For the rest of the variables, the data were taken from the World Bank database. The data covers the period from 2003 to 2016. In the case of real GDP rate, we used provisional data for 2016.

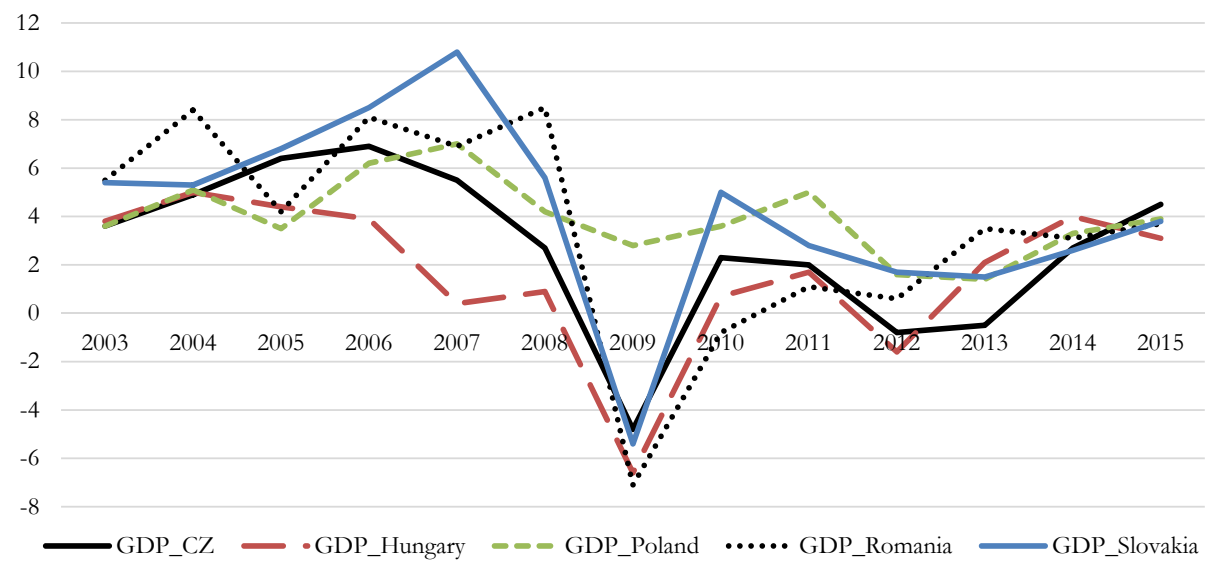

Fig. 1- The evolution of real GDP growth rate in 2003-2015 in V4 countries and Romania. Source: Eurostat.

As Figure 1 indicates, the real GDP growth rate dramatically decreased in the context of global economic crisis in the period 2008-2010. Except Poland, all the other countries in the group were strongly affected by the economic crisis in 2009, when their GDP growth reached negative values. Even in the post-crisis period, all the countries experienced difficulties in returning to pre-crisis dynamics. As a result, it can be stated that in the few years, the main problem for V4 countries will be achieving a high and stable economic growth. Also, for Romania, the government expects a lower level of economic dynamics in the few years, which can result in increasing the problem of high poverty risk and social exclusion. 
Table 1 provides the results of the econometric procedure applied in the research. For all the countries in the sample, the following correlations with the GDP growth were identified:

- Expenditure on R\&D was positively correlated with economic growth in the Czech Republic, Hungary and Romania, but was negatively correlated in Poland and Slovakia;

- FDI had a positive impact on economic growth in all countries, except the Slovak Republic;

- Public expenditure on education had a positive impact on economic growth in the Czech Republic. However, it had a negative impact in the rest of the countries.

Tab. 1- Marginal posterior estimates for generalized Bayesian ridge regress. Source: own estimation.

\begin{tabular}{|l|c|c|c|c|c|c|c|c|c|c|}
\hline \multirow{2}{*}{$\begin{array}{l}\text { Explanato- } \\
\text { ry variable }\end{array}$} & \multicolumn{2}{|c|}{$\begin{array}{c}\text { Czech } \\
\text { Republic }\end{array}$} & \multicolumn{2}{|c|}{ Slovak Republic } & \multicolumn{2}{|c|}{ Poland } & \multicolumn{2}{|c|}{ Hungary } & \multicolumn{2}{|c|}{ Romania } \\
\cline { 2 - 10 } & Est. & PP1SD & Est. & PP1SD & Est. & PP1SD & Est. & PP1SD & Est. & PP1SD \\
\hline $\begin{array}{l}\text { Expendi- } \\
\text { ture on } \\
\text { research } \\
\text { and devel- } \\
\text { opment (\% } \\
\text { of GDP) }\end{array}$ & 0.643 & 0.439 & -0.499 & 0.234 & -0.257 & 0.005 & 6.627 & 0.081 & 0.637 & 0.485 \\
\hline $\begin{array}{l}\text { FDI in- } \\
\text { flows (\% of } \\
\text { GDP) }\end{array}$ & 0.493 & 0.425 & -1.207 & 0.4 & 0.959 & 0.006 & 1.079 & 0.221 & 2.963 & 0.071 \\
\hline $\begin{array}{l}\text { Public ex- } \\
\text { penditure } \\
\text { on educa- } \\
\text { tion (\% of } \\
\text { GDP) }\end{array}$ & 1.18 & 0.488 & -1.941 & 0.181 & -0.158 & 0.312 & -10.526 & 0.093 & -0.736 & 0.182 \\
\hline $\begin{array}{l}\text { Labour } \\
\text { force } \\
\text { having } \\
\text { secondary } \\
\text { education } \\
\text { (\% of total) }\end{array}$
\end{tabular}




\begin{tabular}{|l|l|l|l|l|l|l|l|l|l|l|}
\hline $\begin{array}{l}\text { Employ- } \\
\text { ment rate } \\
(\%)\end{array}$ & 1.686 & 0.320 & -0.662 & 0.344 & 0.155 & 0.277 & 0.284 & 0.584 & 1.241 & 0.251 \\
\hline $\begin{array}{l}\text { Inflation } \\
\text { rate (\%) }\end{array}$ & 0.493 & 0.532 & 0.155 & 0.553 & 0.506 & 0.006 & -1.411 & 0.02 & 0.363 & 0.620 \\
\hline
\end{tabular}

As it was pointed in the previous section, according to the economic theory supported by many empirical cases, human capital and investments in knowledge are a middle and long-term engine of economic growth. More skilled labour resources ensure more returns on R\&D and discoveries are faster absorbed in the economy productive structure. Finally, in the longer term, an increased expenditure on education considered as investment in high quality human capital should support economic growth.

In this context, the negative impact of expenditure on research and development on the economic growth in Poland and Slovakia is contrary to expectations. However, that result is not so uncommon in the empirical literature, especially in the context of a relatively short period of the research, which has been already stressed in the previous section. For example, a close result was obtained by Piech (2007), who compared average gross expenditure on research and development related to the GDP growth rate for UE-27, Turkey, United States and Japan. He also pointed to two cases of countries that were able to obtain a high growth rate with falling expenditure on R\&D. The first case was Slovakia and the second one Ireland. Additionally, Balcerzak and Pietrzak (2015) conducted an analysis of influence of R\&D expenditures on the quality of life measured with HDI in the European Union countries. The dynamic panel data modeling procedure confirmed a structural diversity between "old" and "new" members of the EU and showed a positive influence of R\&D on the quality of life only in the case of highly developed "old" member states.

In current research, public expenditure on education had a positive impact on economic growth only in the Czech Republic and a negative one in the Slovak Republic, Hungary, Poland and Romania. Thus, a change in the level of expenditure on education had no expected outcomes in education quality, which could be measured with its positive influence on outcome dynamics.

In the Czech Republic and Poland, the increase in the percentage of labour force with secondary education generated economic growth. In the Slovak Republic and Hungary, the labour force with secondary education was negatively correlated with the economic growth. Except Poland, in all the other countries the labour force with tertiary education had a negative effect on economic growth.

FDI is commonly considered to be an engine of the economic growth of the host country. Contrary to expectations, FDI had a negative impact on economic growth in Slovakia. However, the result is in line with the findings of Durham (2004) for developing countries and of Malik (2015). A possible explanation for the negative effect of FDI on economic growth could be related to 
the fact that FDI flow consequences are dependent on the technology absorption capacity of the destination states. Other reasons from literature are related to spill over issues (Görg and Greenwood, 2003) or financial conditions specific to receiving countries (Hermes and Lensink, 2003). The positive effects of FDI on economic growth in V4 countries were found by Fifeková and Nemcová (2015). However, the authors showed that this positive effect was caused by FDI inflow in the pre-crisis period.

The employment rate was positively correlated with economic growth in the Czech Republic, Romania and Poland. Contrary to the economic theory, employment had a negative impact on the output growth in Slovakia. Burggraeve et al. (2015) put this correlation on the weakness of the economic recovery. Job market development in the Slovak Republic is strongly related to the economies of foreign business partners, which is in line with the result obtained in regard to the specific influence of FDI in the country. A business sector in Slovakia is very sensitive to the economic decline abroad and the recent economic crisis generated less employment and a slow increase in salaries.

The inflation was negatively correlated with output growth in Hungary and positively connected with economic growth in Poland. The empirical literature confirms that the relation between inflation and GDP growth, especially in the short and middle term, tends to be specific for the country and it depends on the main characteristics of inflationary processes, such as the level of inflation, its variability or the main sources of inflationary pressure. The example of Poland with a relatively stable and low inflation shows a positive correlation between economic growth and inflation. On the other hand, the example of Hungary with a negative influence of inflation on output can be in line with the research of Gokal and Hanif (2004), who showed that inflation might decrease an international competitiveness of the country by decreasing price competitiveness of export. In the next step, it can negatively affect the dynamics of a given economy.

\section{CONCLUSION}

Sustainable economic growth is one of the main objectives of any government. In this context, the main aim of this paper was to identify some determinants of economic growth in Visegrád Group countries and Romania. In the research for the years 2003-2016, a Bayesian approach by the estimations of Bayesian Generalized Ridge regression was applied.

The empirical findings suggested that FDI, public expenditure on education and expenditure on R\&D tend to be correlated with economic growth, but their influence is still specific for the country. Starting with FDI, it supported economic growth in all the countries except the Slovak Republic. In the case of expenditure on education, only in the Czech Republic, it was positively correlated with economic growth, while the expenditure on R\&D had positive effects only in Romania, Hungary and the Czech Republic.

Some policy recommendations are needed in order to ensure a more sustainable economic growth. More attention should be paid to education and research \& development sectors, but the provided empirical research confirms that in that case, the results are not immediate and easy to obtain. A future positive impact of FDI on economic growth in the region will depend on the ability to create an attractive economic environment for highly productive investments that 
additionally provide spill over effects and on the capacity to absorb the positive actual effects of FDI.

The research is limited by the consideration of a relatively small set of mostly economic variables for a limited period of analysis. Thus, in a future study, the first natural step could be extending the analytical period, which mostly depends on the availability and quality of comparable international data. Then, also other factors, especially strictly related to the problem of economy long-term ecological sustainability and socio-political stability, such as institutional, social and political variables or variables concerning effectiveness of energy consumption, or variables showing effectiveness of utilising ecological resources should be included in the research.

\section{Acknowledgement}

This paper has been supported by the New National Excellence Program of the Ministry of Human Capacities.

\section{References}

1. Ambroziak, E., Starosta, P., Sztaudynger, J. J. (2016). Zaufanie, skłonność do pomocy i uczciwość a wzrost gospodarczy w Europie. Ekonomista, 6, 647-671.

2. Balcerzak, A. P., \& Żurek, M. (2011). Foreign Direct Investment and Unemployment: VAR Analysis for Poland in the Years 1995-2009. European Research Studies Journal, 14(1), 4-14.

3. Balcerzak, A. P., \& Pietrzak, M. B. (2015). Research and Development and Quality of Life in European Union Countries. Ekonomia i Prawo. Economics and Law, 14(3), 285-302. DOI: http://dx.doi.org/10.12775/EiP.2015.018.

4. Balcerzak, A. P., \& Pietrzak, M.B. (2016). Quality of Institutions for Knowledge-based Economy within New Institutional Economics Framework. Multiple Criteria Decision Analysis for European Countries in the Years 2000-2013. Economics \& Sociology, 9(4), 66-81. DOI: 10.14254/2071-789X.2016/9-4/4.

5. Barro, R. J. (1991). Economic Growth in a Crosss Section of Countries. Quarterly Journal of Economics, 106(2), pp. 407-443.

6. Bilas, V., Bosnjak, M., \& Cizmic, T. (2016). Relationship between research and development and economic growth in the EU countries. Economic and Social Development: Book of Proceedings, 223.

7. Burggraeve, K., de Walque, G., \& Zimmer, H. (2015). The relationship between economic growth and employment. Economic Review, (i), 32-52.

8. Capello, R., \& Perucca, G. (2015). Openness to globalization and regional growth patterns in CEE countries: from the EU accession to the economic crisis. JCMS: Journal of Common Market Studies, 53(2), 218-236.

9. Cieślik, A. (2014). Globalization and Human Development in Post-Transition Countries: Empirical Evidence from Panel Data. Oeconomia Copernicana, 5(3), 7- 27, DOI: http://dx.doi. org/10.12775/OeC.2014.017.

10. Cuaresma, J. C., Doppelhofer, G., \& Feldkircher, M. (2014). The determinants of economic growth in European regions. Regional Studies, 48(1), 44-67. 
11. Durham, J. B, (2004), "Absorptive capacity and the effects of foreign direct investment and equity foreign portfolio investment on economic growth", European Economic Review, 48(2): 285-306.

12. Fifeková, E., \& Nemcová, E. (2015). Impact of FDI on Economic Growth: Evidence from V4 Countries. Periodica Polytechnica. Social and Management Sciences, 23(1), 7.

13. Gokal, V., \& Hanif, S. (2004). Relationship between inflation and economic growth. Economics Department, Reserve Bank of Fiji.

14. Gorg, H and Greenaway, D. (2004). Much ado about nothing. Do domestic firms really benefit from FDI. The world Bank research Observer, 19(2): 171-197.

15. Gurgul, H., \& Lach, L. (2014). Globalization and economic growth: Evidence from two decades of transition in CEE. Economic Modelling, 36, 99-107.

16. Hamilton, K., Helliwell, J. F., \& Woolcock, M. (2016). Social capital, trust and well-being in the evaluation of wealth (No. w22556). National Bureau of Economic Research.

17. Harrison, L. E., \& Huntington, S. P. (2000). Culture matters: How values shape human progress. Basic books.

18. Hermes, N., \& Lensink, R. (2003). Foreign direct investment, financial development and economic growth. The Journal of Development Studies, 40(1), 142-163.

19. Ivanova, E., Kordos, M., \& Habanik, J. (2015). The competitiveness of V-4 countries within the European Union. Actual Problems of Economics/Aktual'ni Problemi Ekonomiki, 167(5).

20. Iwasaki, I., \& Tokunaga, M. (2013). Macroeconomic Impacts of FDI in Transition Economies: A Meta-Study. In 7th MAER-Net Colloquium at the University of Greenwich, London, UK.

21. Karabatsos, G. (2014). Fast Marginal Likelihood Estimation of the Ridge Parameter (s) in Ridge Regression and Generalized Ridge Regression for Big Data. arXiv preprint arXiv:1409.2437.

22. Kasperowicz, R., \& Štreimikienè, D. (2016). Economic growth and energy consumption: comparative analysis of V4 and the "old" EU countries. Journal of International Studies, 9(2), 181-194.

23. Kasperowicz, R., \& Štreimikiené, D. (2016). Economic growth and energy consumption: comparative analysis of V4 and the "old" EU countries. Journal of International Studies, 9(2), 181-194.

24. Kondratiuk-Nierodzińska, M. (2016). New Knowledge Generation Capabilities and Economic Performance of Polish Regions. Equilibrium. Quarterly Journal of Economics and Economic Policy, 11(3), 451-471. DOI: http://dx.doi.org/10.12775/EQUIL.2016.021.

25. Lindley, D. V., \& Smith, A. F. (1972). Bayes estimates for the linear model. Journal of the Royal Statistical Society. Series B (Methodological), 1-41.

26. Mahdi Ghodsi, M. \& Michalek, J. J. (2016). Technical Barriers to Trade Notifications and Dispute Settlement within the WTO. Equilibrium. Quarterly Journal of Economics and Economic Policy, 11(2), 219-249. DOI: http://dx.doi.org/10.12775/ EQUIL.2016.010. 
27. Malik, K. (2015). Impact of Foreign Direct Investment on Economic Growth of Pakistan. American Journal of Business and Management, 4(4), 190-202.

28. Moura, R., \& Forte, R. (2010). The effects of foreign direct investment on the host country economic growth-theory and empirical evidence (No. 390). Universidade do Porto, Faculdade de Economia do Porto.

29. Nežinský, E., \& Fifeková, E. (2014). The V4: a Decade after the EU Entry. Entrepreneurial Business and Economics Review, 2(2), 31-46.

30. Piech, K. (2007). Knowledge economy and the long-term growth - are there any relations? In K. Piech (Ed.). Knowledge and innovation process in Central and East European economies. Warsaw: The Knowledge \& Innovation Instutute, pp. 30-32.

31. Pietrzak, M. B. \& Balcerzak, A. P (2016). Quality of Human Capital and Total Factor Productivity in New EU Member States. In T. Loster \& T. Pavelka (Eds.). The 10th International Days of Statistics and Economics. Conference Proceedings. September 8-10, 2016. Prague: Libuse Macakova, Melandrium, pp. 1492-1501. Retrieved form: http://econpapers.repec. org/bookchap/pesecchap/20.htm

32. Popa, A. M. (2012). The Impact of Social Factors on Economic Growth: Empirical Evidence for Romania and European Union Countries. Romanian Journal of Fiscal Policy (RJFP), 3(2), 1-16.

33. Próchniak, M. (2011). Determinants of economic growth in Central and Eastern Europe: the global crisis perspective. Post-communist economies, 23(4), 449-468.

34. Radu, M. (2015). The impact of political determinants on economic growth in CEE countries. Procedia-Social and Behavioral Sciences, 197, 1990-1996.

35. Sala-I-Martin, X.X. (1997). I Just Ran Two Million Regressions. American Economic Review, 87(2), pp. 178-183

36. Sass, M., \& Fifekova, M. (2011). Offshoring and outsourcing business services to Central and Eastern Europe: Some empirical and conceptual considerations. European Planning Studies, 19(9), 1593-1609.

37. Simionescu, M. D. (2016). The Relationship Between Foreign Direct Investment And Economic Growth In Bulgaria, Romania And Croatia During The Recent Economic Crisis. Internal Auditing and Risk Management, 42(1), 149-158.

38. Stefaniak-Kopoboru, J., \& Kuczewska, J. (2016). Export Specialization in Services of the Visegrad Countries. Equilibrium. Quarterly Journal of Economics and Economic Policy, 11(2), 265284. DOI: http://dx.doi.org/10.12775/ EQUIL.2016.012.

39. Supińska, J. (2013). Does human factor matter for economic growth? Determinants of economic growth process in CEE countries in light of spatial theory. Bank $i$ Kredyt, 44(5), 505-532.

40. Witkowski, B. (2007). Can R\&D expenditure be found a growth factor in the EU countries? In K. Piech (Ed.). Knowledge and innovation process in Central and East European economies. Warsaw: The Knowledge \& Innovation Instutute, pp. 43-60/

41. Vojtovic, S. (2013). The impact of emigration on unemployment in Slovakia. Inzinerine Ekonomika-Engineering Economics, 24(3): 207-216. 
42. Zak, P. J. \& Knack, S. (2001). Trust and growth. The economic journal, 111(470), 295-321.

\section{Contact information}

Habilitated Dr. Mibaela Simionescu

Romanian Academy, Institute for Economic Forecasting

Calea 13 Septembrie 13, 76001 Bucharest, Romania

Email:mihaela_mb1@yahoo.com

Habilitated Dr. Kornélia Lazányi

Óbuda University, Keleti Faculty of Business and Management

Bécsi st., 96/b, 1034, Budapest, Hungary

Email:lazanyi.kornelia@kgkk.uni-obuda.bu

Mgr. Ing. Gabriela Sopková, PhD.

University of Economics in Bratislava

Faculty of Commerce

Dolnozemská cesta 1, 85235 Bratislava, Slovak Republic

Email:gabika.sopkova@gmail.com

Ing. Kamil Dobes, Ph.D.

Tomas Bata University in Zlin

Faculty of Management and Economics

Mostni 5139, 76001 Zlín, Czech Republic

Email:dobes@fame.utb.cr.

Adam P. Balcerzak, PhD

Nicolaus Copernicus University

Faculty of Economic Sciences and Management

Ul. Gagarina $13 a$

87-100 Toruń, Poland

Email:adam.balcerzak@umk.pl 